\title{
MENINGKATKAN HASIL BELAJAR MATEMATIKA PADA MATERI OPERASI HITUNG CAMPURAN SISWA KELAS IV SD DENGAN MODEL PEMBELAJARAN KOOPERATIF TIPE TEAMS GAMES TOURNAMENTS (TGT)
}

\author{
Asep Priatna ${ }^{1}$ \\ Fahma Safitri² \\ 1Dosen STKIP Subang \\ ${ }^{2}$ SD Negeri Rahayu \\ 1asep_priatna@yahoo.co.id \\ 2fahma.safitri@yahoo.com
}

\begin{abstract}
Application of Experimental Methods to Increase Understanding of the Concept of Grade IV Primary School Students in Science Lesson. The purpose of this study is to describe data on: (1) student activity in science learning by applying experimental method; (2) improvement of understanding of science concept by applying experiment method. The method used in this research is a classroom action research with Kemmis $n$ Mc design. Taggart. This research was conducted in the odd semester of academic year 2017/2018 at SD Negeri Wirukencana in grade 4 students. Data collection techniques used are observation, test and documentation. Based on the processing and data analysis, the results of this study are: (1) Student activity at the time of learning using experimental method that is in the first stage students pay attention to the initial experiments conducted by the teacher as evidenced by answering questions asked by teachers around the experiment. Then at the observation stage all the students recorded things that happened while observing the experiments performed by the teacher. The third stage of the students make a hypothesis according to the conceptual observation based on observation. Furthermore, in the verification stage students conduct experiments that refer to the LKS in a group way, the students divide each task on each member of the group such as the task as chairman of the group, secretary, moderator and other tasks in the experiment. After the students complete the experiment each group discuss or present the results of his group's observations in front of the class. The fifth stage is the application of concepts, the students are able to give examples of the alteration of changes in the form of things in everyday life; and (2) The application of experimental methods in general can increase the understanding of the concept of fourth grade students.
\end{abstract}

Keywords: Experiment Method, Concept Understanding 


\begin{abstract}
ABSTRAK
Metode ceramah merupaka salah satu metode yang paling sering digunakan dalam pembelajran Matematika di SD. Seperti di SD Negeri Rahayu, guru menyampaikan materi secara lisan, siswa mencatatnya di buku dan kurang tertarik, sehingga pembelajran menjadi kurang bermakna dan berdampak pada hasil belajar yang tidak optimal. Model kooperatif tipe Teams Games Tournaments dapat menjadi alternatif pembelajaran Matematika. Tujuan penelitian ini yaitu Ingin mengetahui hasil belajar siswa kelas IV SD dalam pembelajaran Matematika sebelum menggunakan model pembelajaran kooperatif tipe Team Games Tournament, aktifitas siswa kelas IV SD dalam proses pembelajaran Matematika dengan menggunakan model pembelajaran kooperatif tipe Team Games Tournament, dan hasil belajar siswa kelas IV SD setelah menggunakan model pembelajaran kooperatif tipe Teams Games Tournament. Hasil penelitian menujukkan bahwa pembelajaran matematika dengan model kooperatif tipe Teams Games Tournament dapat meningkatkan hasil belajar matematika materi operasi hitung campuran pada siswa kelas IV SD Negeri Rahayu. Hal tersebut dapat dilihat dari rata-rata nilai kelas yang baik dan telah mencapai KKM (Kriteria Kemampuan Minimal) yang telah ditentukan yaitu 65. Rata-rata nilai kelas pada siklus I adalah 65,1. Pada siklus II, rata-rata nilai kelas meningkat menjadi 77 . Setelah perbaikan pada siklus III, rata-rat nilai kelas meningkat menjadi 87 . Model ini juga dapat meningkatkan atifitas siswa agar lebih aktif dalam proses pembelajaran, bersosialisasi dengan siswa lain, bertanggung jawab terhadap kelompok, dan berkompetensi secara sehat.
\end{abstract}

Kata Kunci: Model kooperatif tipe Teams Games Tournamet (TGT), Matematika, Operasi Hitung Campuran, Hasil belajar. 


\section{A. Pendahuluan}

\section{Pendidikan}

merupakan

penentu kemajuan suatu bangsa.

Berhasil tidaknya pendidikan yang dilaksanakan akan menentukan maju mundurnya suatu bangsa.

Pendidikan merupakan salah satu bentuk perwujudan kebudayaan manusia yang dinamis dan akan terus berkembang seiring dengan perkembangan, tentunya tidak akan lepas dari masalah. Salah satu masalahnya yang dihadapi bangsa Indonesia adalah rendahnya mutu pendidikan. Fasilitas, sarana, media dan sumber merupakan fasilitator yang membantu mendorong dan membimbing peserta didik dalam proses belajar mengajar guna memperoleh keberhasilan dalam mengajar.

Menurut undang-undang No. 20 Tahun 2003 pendidikan merupakan usaha sadar dan terencana untuk mewujudkan suasana belajar dan proses pembelajaran agar siswa secara aktif mengembangkan potensi dirinya utuk memilii kekuatan spiritual keagamaan, pengendalian diri, kepribadian, kecerdasan, akhlak mulia, serta keterampilan yang diperlukan dirinya, masyarakat, Bangsa dan Negara (Depdiknas. 2003:5). Dalam pendidikan agar proses pebelajaran dikelas dapat maksimal dan optimal, maka hubungan antara guru dan siswa, hubungan siswa dan siswa harus adanya timbal balik yang positif satu sama lain.

Matematika merupakan salah satu ilmu pengetahuan yang memiliki peranan yang sangat penting dalam kehidupn manusia. Matematika memberikan kontribusi yang sangat besar, mulia dari yang sederhana sampai yang kompleks, mulai dari yang abstrak sampai yang konkrit untuk pemecahan masalah dalam segala bidang. Matematika sendiri pada dasarnya memiliki objek dasar yang abstrak. Menurut Soejadi (dalam Muhsetyo 2000) keabstrakan matematika kaena objek dasarnya abstrak, yaitu fakta, konsep, operasi dan prinsip. Sedangkan menurut Piaget, siswa sekolah dasar yang umumnya berkisar antara 6 atau 7 tahun sampai 12 atau 13 tahun, berada pada fase operasional 
konkret atau cenderung berpikir konkret, rasional dan objektif dalam memahami situasi.

KTSP (2006) Matematika merupakan ilmu universal yang mendasari perkembangan teknologi modern, mempunyai peran penting dalam berbagai disiplin dan memajukan daya pikir manusia. Perkembangan pesat di bidang teknologi informasi dan komunikasi dewasa ini dilandasi oleh perkembangan matematika di bidang teori bilangan, aljabar, analisis, teori peluang, dan diskrit. Untuk mengusai dan menciptakan teknologi di masa depan diperlukan penguasaan matematika yang kuat sejak dini. Salah satu mata pelajaran yang dianggap rumit dan membosankan untuk diberikan kepada siswa adalah mata pelajaran matematika, disamping kurang diminati siswa dalam penyampain materi pelajaran guru juga kurang inovatif dan kreatif dalam menggunakan pembelajan.

Dari hasil pengamatan yang di lakukan terhadap siswa kelas IV SD Negeri Rahayu, Tahun ajaran 2017-2018 pada mata pelajaran matematika materi operasi hitung campuran. Siswa menunjukan kesulitan dalam memahami materi yang di ajarkan oleh guru, sehingga hasil belajar siswa belum memenuhi KKM yang di tetapkan (65). Penyebab masih rendahnya hasil belajar operasi hitung adalah pelaksanaan proses belajar mengajar masih di lakukan secara konvensiona, dalam menyajikan pembelajaran hanya menggunkan metode ceramah dan siswa hanya disuruh mencatat materi yang di sampaikan.

Ketika siswa kesulitan dalam menyelesaikam soal operasi hitung. Faktor utamanya mungkin, karena siswa tidak memahami apa yang diajarkan oleh guru. Perhatian siswa dalam proses pembelajaran di kelas diartikan sebagai pemusatan tenaga jiwa siswa yang tertuju kepada sajian materi yang dijelaskan oleh guru pada saat proses pembelajaran di kelas sedang berlangsung. Seorang siswa dianggap memiliki perhatian belajar terhadap materi pelajaran yang diajarkan oleh guru di kelas, jika siswa tersebut memusatkan perhatianya dengan cara memfokuskan pandangannya ke 
depan untuk memperatikan materi yang disajikan oleh guru dengan memusatkan kesadaran dan daya jiwanya untuk mengetahui dan memahami materi pelajaran yang disajiakan oleh guru di kelas. Manrihu (dalam Hadis, A. 2006:23) menyebutkan:

"Perhatian belajar yang dimiliki oleh peserta didik dan manusi pada umumnya dibagi atas beberapa macam diantaranya perhatian intensif dan tidak intensif,perhatian sepontan dan perhatian sekehendak perhatian terpencar, perhatian terpusat dan perhatian campuran".

Kendala demikian membuat peneliti sekaligus sebagai calon pendidik sangat prihatin dan merasa bersalah dalam mendidik siswa-siswi sekolah dasar, karena hasil belajar yang tuntas sesuai dengan kriteria ketuntasan minimal yang ditetapkan. Dengan alasan tersebut penulis menjadi tertarik untuk mengubah sistem pembelajaran Matematika di kelas IV (empat) pada siswa SD dengan menyajikan pembelajaran Matematika melalui model pembelajaran inkonvesional, yang $\begin{array}{lrr}\text { tujuan } & \text { utamanya } & \text { untuk } \\ \text { mengaktifkan } & \text { siswa. } & \text { Model } \\ \text { pembelajaran } & \text { yang } & \text { mampu }\end{array}$ membuat siswa sebagai actor dan guru sebagai fasilitator saja. Ada beberapa model pembelajaran yang di kembangkan para ahli dalam usaha mengoptimalkan hasil belajar siswa. Dari berbagai tipe model pembelajaran kooperatif yang ada. Model pemelajaran kooperatif tipe Teams Games Tournament (TGT), karena dalam pembelajaran kooperatif tipe ini tidak hanya bekerja dalam kelompok saja, namun terdapat permainan yang tersaji dalam game yang disajikan secaa turnamen.

Pengertian hasil belajar menurut Sudjana (2008:22) adalah kemampuan-kemampuan yang dimiliki siswa setelah ia menerima pengalaman belajarnya. Penilaian hasil belajar adalah suatu peruses pemberian nilai terhadap hasil-hasil belajar yang dicapai siswa dengan kriteria tertentu. Penilaian hasil belajar pada hakikatnya yaitu perubahan tingkah laku yang diinginkan pada diri siswa setelah terjadi melalui proses pembelajaran. 
Menurut Sanjay (dalam Rusman. 2012:203) Coopeative learning merupakan kegiatan belajar siswa yang dilakukan dengan cara berkelompok. Model pembelajaran kelompok adalah rangkaian kegiatan belajar yang dilakukan oleh siswa dalam kelompok-kelompok tertentu untuk mencapai tujuan pembelajaan yang telah dirumuskan. Menurut Salvin (2010:13) pemebelajaran kooperatif tipe TGT merupakan suatu pendekatan kerja sama antar kelompok dengan menggunakan turnamen sebagai pengganti kuis. Inti dari model ini adalah adanya game dan turnamen akademik. Dunia anak adalah dunia bermain. Dan hampir semua anak menyukai permainan dan hal yang menyenangkan. Model pembelajaran kooperatif tipe Teams Games Tournaments (TGT) adalah pembelajaran berkelompok yang memungkinkan siswa dapat belajar lebih rileks di samping menumbuhkan tanggung jawab, kerjasama, dan persaingan sehat.

\section{B. Metode Penelitian}

Metode penelitian yang digunakan dalam penelitian ini adalah Penelitian Tindakan Kelas (Classroom Action Research). Hopkins (Muslich, M. 2009:8) menjelaskan bahwa penelitian tindakan kelas adalah suatu bentuk kajian yang bersifat reflektif, yang dilakukan oleh pelaku tindakan untuk meningkatkan kemantapan rasional dari tindakan-tindakannya dalam melaksanakan tugas dan memperdalam pemahaman terhadap kondisi dalam praktik pembelajaran.

1. Lokasi Penelitian

Penelitian ini dilaksanakan di SDN Rahayu yang berlokasi di Desa Sukamelang Kecamatan Subang Kabupaten Subang pada semester ganjil Tahun ajaran 2017/2018.

\section{Subjek Penelitian}

Subjek penelitian ini adalah siswa kelas IV SDN Rahayu yang berjumlah 30 orang terdiri dari 17 siswa laki-laki dan 13 siswa perempuan.

\section{Pembahasan Hasil Penelitian \\ Pelaksanaan penelitian} tindakan kelas ini dilaksanakan sebanyak tiga siklus, dimana setiap siklus terdiri dari dua kali 
pertemuan, pada pembahasan hasil penelitian ini, peneliti akan membahas mengenai penerapan model pembelajaran Teams Games Tournament dalam upaya meningkatkan hasil belajar siswa materi operasi hitung campuran , hasil belajar siswa dalam materi operasi hitung campuran sesudang menggunakan model pembelajaran Teams Games Tournament, dan Respon siswa terhadap model pembelajaran Teams Games Tournament dalam Matematika. Aapun hasil penelitian tersebut, sebgai berikut:

\section{Pelaksanaan Tindakan Siklus I}

a. Perencanaan

Berdasarkan pengamatan pada kondsi awal, penelitian melakukan penelaahan terhadap Standa Kompetensi (SK) dan Kompetensi Dasar (KD) berdasarkan Kuriulum Tingkat Satuan Pendidikan (KTSP) untuk mempersiapkan scenario pembelajaran yang dapat meningkatkan hasil belajr siswa pada materi operasi hitung campuran .skenario yang disusun mrupakan scenario yang menggunkan model pembelajaran
Teams Games Tournamet Adapun

Perencanaannya sebagi berikut:

1) Membuat RPP agar plaksanaan proses belajar mengajar berjalan sesuai dengan yang diharapkan, sekaligus sebgai pedoman penelitian dalam melaksanakan pembelajaran, adapun indikator capaian kompetensi yang digunakan pada pembelajaran siklus I ini adalah menjelaskan tingkatan dalam hitung campuran dan memberikan contoh soal hitung campuran.

2) Mempersiapkan bahan ajar, media serta perlengkapan yang di perlukan dalam kegiatan pembelajran. Adapun media pembelajaran yang di terapkan adalah media berbentuk kartu soal.

3) Membuat Lembar Kerja Siswa (LKS) untuk kelompok. Pada setiap siklus siswa akan mengerjakan LKS kelompok sesuai materi yang di ajarkan siswa harus mampu bekerjasama untuk menyelesaikan tugas yang diberikan.

4) Menyusun instrument tes evaluasi untuk mengetahui 
peningkatan hasil belajar sisiwa, tes evaluasi untuk mengetahui yang dibuat adala sebanyak 5 butir soal esai.

5) Mengkonsultasikan instrument penelitian kepada dosen pembimbing. Siklus I terlaksana dalam satu kali pertemuan. Dalam pelaksanaan tindakan, dilakukan pengamatan berbagai komponen melalui lembar observasi aktifitas guru dan siswa. Penelitian mebagi siswa menjadi empat kelompok

b. Tindakan Awal

Pelaksanaan siklus

dilakukan pada hari Jum'at tanggal 1 September 2017, dimulai pukul 07:30 sampai 08:40 WIB dikelas IV SD Negeri Rahayu. Tahap kegiatan siklus I dimulai saat penelitian memasuki kelas pada pukul 07:30 WIB. Setelah siswa melakukan baris-berbaris didepan kelas, peneliti mengkondisikan siswa pada situasi pembelajaran yang kondusif dan menutun siswa untuk berdo'a bersama. Setelah berdo'a peneliti mengabsen siswa untuk mengetahui tingkat kehadiran siswa. Pada hari ini jumlah siswa yang hadir sebanyak 30 orang atau $100 \%$ siswa hadir.

Peneliti menyampaikan tujuan pembelajran dan mempersiapkan siswa. Peneliti menjelaskan tentang operasi campuran, memberikan contoh tentang soal operasi campuran, dan mempersiapkan siswa untuk belajar dengan sedikit pemanasan (brain game. Siswa menyimak dan mencatat apa yang dijelaskan oleh guru. Peneliti mengadakan tanya jawab dari hasil penjelasan yang sudah diberikan. Peneliti membagi siswa menjadi 6 kelompok belajar dan setiap kelompoknya beranggota 5 orang.

c. Tindakan Inti

1) Tahap Presentasi Kelas

Pada tahap tindakan inti, peneliti memberikan soal pada setiap meja turnamen dengan jenis soal yang berbeda sesuai dengan kemampuan pada setiap kelompok. Pengundian ditentukan untuk menentukan kedudukan peserta turnamen dalam turnamen pertama, apakah sebagai pembaca soal,penantang pertama, penentang kedua yang disertai tugasnya masing-masing. Untuk 
putaran selanjutnya kedudukan

peserta di lakukan secara

bergantian, menurut arah jarum jam, sampai waktu turnamen selesai.

Siswa yang menjawab pertanyaanya benar, akan mendapatkan skor. Setiap perwakilan kembali pada anggota kelompoknya masing-masing dan memberitahukan kepada anggota kelompoknya tentang perolehan skor dan pertanyaan games. Siswa diberikan latihan soal mengenai opeasi hitung campuran Siswa membantu teman sekelompoknya yang belum paham benar dalam mengerjakan soal. Peneliti bertanya tentang hal-hal yang belum dipahami siswa. Peneliti memberikan reward berupa pujian kepada kelompok turnamen yang mendapatkan nilai tertinggi dan memberikan penguatan kepada siswa.

2) Tahap Berlajar Kelompok

Agar siswa paham mengenai materi tersebut, peneliti membagikan Lembar Kerja Siswa (LKS). Masing-masing kelompok mendapatkan 1 LKS untuk dikerjakan secara berkelompok.
Peneliti memberikan 15 menit kepada setiap kelompok untuk mengisi LKS tersebut. Pada saat pengerjaan LKS, peneliti bersama observer berkeliling untuk mengamati siswa. Setelah diamati, ada beberapa siswa yang tidak ikut serta dalam pengerjaan LKS bersama kelompoknya. Peneliti kemudian menghampiri siswa yang tidak ikut berpartisipasi dalam mengerjakan LKS tersebut dan menanyakan alasan mengapa mereka tidak ikut serta dalam pengerjaan LKS. Beberapa orang dari mereka beralasan bahwa sudah banyak yang mengerjakan sehingga mereka merasa tidak perlu ikut serta mengerjakan LKS.

Untuk mengatasi kekeliruan tersebut, peneliti mengulangi apa yang telah dijelaskan pada awal pembelajaran. Bahwa ini adalah pembeljaran kelompok, jadi segala sesuatu harus dilakukan dan dikerjakan bersama-sama, karena keberhasilan kelompok beukan karena beberapa anggota saja. Setelah peneliti menjelaskan hal tersebut, kemudian seluruh siswa mulai aktif bekerja sama dalam pengerjaan LKS. Setelah 15 menit, 
peneliti meminta sisw akelompok untuk mengumpulkan LKS yang telah dikerjakan dan bersiap-siap untuk kegiatan turnamaen.

3) Tahap Turnamen

Pada tahap turnamen ini, akan dilakukan game dimana setiap siklus siswa akan dibagi kedalam 6 meja turnamen, masingmasing meja berisi 4-5 orang dengan kemampuan yang sma (tinggi, diatas rata-rata, rata-rat, rendah) dan 5 kartu pertanyaan observasi memabantu penelitl untuk mengkondisikan siswa yang berebut tempat duduk agar tidak terjadi keributan. Setelah semua duduk di meja masing-masing turnamen , kemudian peneliti membagikan kartu soal dan kartu jawaban. Aturanya permainannya satu orang siswa mengambil kartu soal dan satu orang siswa mengambil kartu jawaban. Ketika siswa yang mengambil kartu soal menjawab benar, maka kartu soal dan kartu jawaban di simpan di dalam tempat pengumpulan kartu di setiap meja turnamen. Siswa yang menjawab soal pertanyaan benar mendapatkan skor 10 dan mencatatnya pada kartu perolehan skor. Ketika siswa yang mengambil kartu soal menjawab salah maka kartu soal dan jawaban di simpan kembali bagian bawah pada tumpukan soal pertanyaan dan jawaban.

Pada sesi pertama hampir $50 \%$ dari peserta tidak dapat menjawab soal dengan baik yang ada dalam kartu soal. Setelah ditelusuri, ternyata mereka tidak mampu menjawab pertanyaan rata-rata beralasan tidak ikut membaca materi dan mendengarkan apa yang pneliti jelaskan pada saat tahap presentasi kelas.

4) Tahap Perhitungan Skor Dan Penghagaan

Pada tahap ini, peneliti meminta tiap kelompok mengumpulkan dan menghitung jumlah kartu soal yang telah berhasil dijawab untuk diubah menjadi poin. Kelompok yang masuk kategori Super Great yaitu Leci, dan yang masuk kategori Great Team yaitu apel dengan skor 60 , anggur dengan skor60, durian dengan skor 60 , strawberrydengan skor 70 , melon dengan skor 60 .

5) Observasi Siswa 


\begin{abstract}
Kegiatan observasi ini dilakukan oleh peneliti selama pembelajaran berlangsung. Hal ini yang diamati oleh observer adalah proses belajar atau aktivitas siswa dalam pembelajaran. Pengamatan yang dilakukan sesuai dengan pedoman observasi yang berisi aktivitas yang sesuai dengan Model Pembelajaran Teams Games Tounament (TGT). Sedangkan berdasarkan lembar observasi pada aktfitas belajar siswa dapat disimpulkan bahwa aktivitas belajar siswa yang mendominasi skala B. yang merupakan masuk kategori Baik dengan nilai 71,8 dalam lembar observasi.
\end{abstract}

\section{Pelaksanaan Tindakan Siklus II}

a. Perencanaan

Berdasarkan pengamatan pada kondsi awal, penelitian melakukan penelaahan terhadap Standa Kompetensi (SK) dan Kompetensi Dasar (KD) berdasarkan Kuriulum Tingkat Satuan Pendidikan (KTSP) untuk mempersiapkan scenario pembelajaran yang dapat meningkatkan hasil belajr siswa pada materi operasi hitung campuran .skenario yang disusun mrupakan scenario yang menggunkan model pembelajaran Teams Games Tournamet Adapun Perencanaannya sebagi berikut:

1) Membuat RPP agar plaksanaan proses belajar mengajar berjalan sesuai dengan yang diharapkan, sekaligus sebgai pedoman penelitian dalam melaksanakan pembelajaran, adapun indikator capaian kompetensi yang digunakan pada pembelajaran siklus II ini adalah menjelaskan tingkatan dalam hitung campuran dan memberikan contoh soal hitung campuran.

2)Mempersiapkan bahan ajar, media serta perlengkapan yang di perlukan dalam kegiatan pembelajran. Adapun media pembelajaran yang di terapkan adalah media berbentuk kartu soal.

3) Membuat Lembar Kerja Siswa (LKS) untuk kelompok. Pada setiap siklus siswa akan mengerjakan LKS kelompok sesuai materi yang di ajarkan siswa harus mampu bekerjasama untuk menyelesaikan tugas yang diberikan. 
4) Menyusun instrument tes evaluasi untuk mengetahui peningkatan hasil belajar sisiwa, tes evaluasi untuk mengetahui yang dibuat adala sebanyak 5 butir soal esai.

5) Mengkonsultasikan instrument penelitian kepada dosen pembimbing. Siklus II terlaksana dalam satu kali pertemuan. Dalam pelaksanaan tindakan, dilakukan pengamatan berbagai komponen melalui lembar observasi aktifitas guru dan siswa. Penelitian mebagi siswa menjadi empat kelompok

b. Tindakan Awal

Pelaksanaan siklus II dilakukan pada hari Senin tanggal 4 September 2017, dimulai pukul 07:30 sampai 08:40 WIB dikelas IV SD Negeri Rahayu. Tahap kegiatan siklus II dimulai saat penelitian memasuki kelas pada pukul 07:30 WIB. Setelah siswa melakukan baris-berbaris didepan kelas, peneliti mengkondisikan siswa pada situasi pembelajaran yang kondusif dan menutun siswa untuk berdo'a bersama. Setelah berdo'a peneliti mengabsen siswa untuk mengetahui tingkat kehadiran siswa. Pada hari ini jumlah siswa yang hadir sebanyak 30 orang atau $100 \%$ siswa hadir.

Peneliti menyampaikan tujuan pembelajaran dan mempersiapkan siswa. Peneliti menjelaskan tentang operasi campuran, memberikan contoh tentang soal operasi campuran, dan mempersiapkan siswa untuk belajar dengan sedikit pemanasan (brain game). Siswa menyimak dan mencatat apa yang dijelaskan oleh guru. Peneliti mengadakan tanya jawab dari hasil penjelasan yang sudah diberikan. Peneliti menyedikan media congklak untuk Peneliti membagi siswa menjadi 6 kelompok belajar dan setiap kelompoknya beranggota 5 orang.

c. Tindakan Inti

1) Tahap Presentasi Kelas

Pada tahap tindakan inti, peneliti memberikan soal pada setiap meja turnamen dengan jenis soal yang berbeda sesuai dengan kemampuan pada setiap kelompok. Pengundian ditentukan untuk menentukan kedudukan peserta turnamen dalam turnamen pertama, apakah sebagai pembaca soal,penantang pertama, 
penentang kedua yang disertai tugasnya masing-masing. Untuk putaran selanjutnya kedudukan peserta dilakukan secara bergantian, menurut arah jarum jam, sampai waktu turnamen selesai.

Siswa yang menjawab pertanyaanya benar, akan mendapatkan skor. Setiap perwakilan kembali pada anggota kelompoknya masing-masing dan memberitahukan kepada anggota kelompoknya tentang perolehan skor dan pertanyaan games. Siswa diberikan latihan soal mengenai opeasi hitung campuran Siswa membantu teman sekelompknya yang belum paham benar dalam mengerjakan soal. Peneliti bertanya tentang hal-hal yang belum dipahami siswa. Peneliti memberikan reward berupa pujian kepada kelompok turnamen yang mendapatkan nilai tertinggi dan memberikan penguatan kepada siswa.

2) Tahap Berlajar Kelompok

Agar siswa paham mengenai materi tersebut, peneliti membagikan Lembar Kerja Siswa (LKS). Masing-masing kelompok mendapatkan 1 LKS untuk dikerjakan secara berkelompok. Peneliti memberikan 15 menit kepada setiap kelompok untuk mengisi LKS tersebut. Pada saat pengerjaan LKS, peneliti bersama observer berkeliling untuk mengamati siswa. Setelah diamati, ada beberapa siswa yang tidak ikut serta dalam pengerjaan LKS bersama kelompoknya. Peneliti kemudian menghampiri siswa yang tidak ikut berpartisipasi dalam mengerjakan LKS tersebut dan menanyakan alasan mengapa mereka tidak ikut serta dalam pengerjaan LKS. Beberapa orang dari mereka beralasan bahwa sudah banyak yang mengerjakan sehingga mereka merasa tidak perlu ikut serta mengerjakan LKS.

Untuk mengatasi kekeliruan tersebut, peneliti mengulangi apa yang telah dijelaskan pada awal pembelajaran. Bahwa ini adalah pembeljaran kelompok, jadi segala sesuatu harus dilakukan dan dikerjakan bersama-sama, karena keberhasilan kelompok beukan karena beberapa anggota saja. Setelah peneliti menjelaskan hal tersebut, kemudian seluruh siswa 
mulai aktif bekerja sama dalam pengerjaan LKS. Setelah 15 menit, peneliti meminta sisw akelompok untuk mengumpulkan LKS yang telah dikerjakan dan bersiap-siap untuk kegiatan turnamaen.

3) Tahap Turnamen

Pada tahap turnamen ini, akan dilakukan game dimana setiap siklus siswa akan dibagi kedalam 6 meja turnamen, masingmasing meja berisi 4-5 orang dengan kemampuan yang sma (tinggi, diatas rata-rata, rata-rat, rendah) dan 5 kartu pertanyaan observasi memabantu penelit। untuk mengkondisikan siswa yang berebut tempat duduk agar tidak terjadi keributan. Setelah semua duduk di meja masing-masing turnamen , kemudian peneliti membagikan kartu soal dan kartu jawaban. Aturanya permainannya satu orang siswa mengambil kartu soal dan satu orang siswa mengambil kartu jawaban. Ketika siswa yang mengambil kartu soal menjawab benar, maka kartu soal dan kartu jawaban di simpan di dalam tempat pengumpulan kartu di setiap meja turnamen. Siswa yang menjawab soal pertanyaan benar mendapatkan skor 10 dan mencatatnya pada kartu perolehan skor. Ketika siswa yang mengambil kartu soal menjawab salah maka kartu soal dan jawaban di simpan kembali bagian bawah pada tumpukan soal pertanyaan dan jawaban.

Pada sesi kedua hampir 30\% dari peserta tidak dapat menjawab soal dengan baik yang ada dalam kartu soal. Setelah ditelusuri, ternyata mereka tidak mampu menjawab pertanyaan rata-rata beralasan tidak ikut membaca materi dan mendengarkan apa yang peneliti jelaskan pada saat tahap presentasi kelas.

4) Tahap Perhitungan Skor Dan Penghagaan

Pada tahap ini, peneliti meminta tiap kelompok mengumpulkan dan menghitung jumlah kartu soal yang telah berhasil dijawab untuk diubah menjadi poin. Kelompok yang masuk kategori Super Great yaitu Anggur skor 80, durian skor 100 , Leci skor 100, dan yang masuk kategori Great Team yaitu apel dengan skor 70, , 
strawberrydengan skor 70 , melon dengan skor 70 .

5) Observasi Siswa

Kegiatan observasi ini dilakukan oleh peneliti selama pembelajaran berlangsung. Hal ini yang diamati oleh observer adalah proses belajar atau aktivitas siswa dalam pembelajaran. Pengamatan yang dilakukan sesuai dengan pedoman observasi yang berisi aktivitas yang sesuai dengan Model Pembelajaran Teams Games Tounament (TGT). Sedangkan berdasarkan lembar observasi pada aktfitas belajar siswa dapat disimpulkan bahwa aktivitas belajar siswa yang mendominasi skala B. Yang merupakan masuk kategori baik dengan skor 75 dalam lembar observasi.

\section{Pelaksanaan Tindakan Siklus} III

a. Perencanaan

Berdasarkan pengamatan pada kondsi awal, penelitian melakukan penelaahan terhadap Standa Kompetensi (SK) dan Kompetensi Dasar (KD) berdasarkan Kuriulum Tingkat Satuan Pendidikan (KTSP) untuk mempersiapkan scenario pembelajaran yang dapat meningkatkan hasil belajr siswa pada materi operasi hitung campuran. Skenario yang disusun mrupakan scenario yang menggunkan model pembelajaran Teams Games Tournamet Adapun Perencanaannya sebagi berikut:

1) Membuat RPP agar pelaksanaan proses belajar mengajar berjalan sesuai dengan yang diharapkan, sekaligus sebgai pedoman penelitian dalam melaksanakan pembelajaran, adapun indikator capaian kompetensi yang digunakan pada pembelajaran siklus III ini adalah menjelaskan tingkatan dalam hitung campuran dan memberikan contoh soal hitung campuran.

2) Mempersiapkan bahan ajar, media serta perlengkapan yang di perlukan dalam kegiatan pembelajran. Adapun media pembelajaran yang di terapkan adalah media berbentuk kartu soal.

3) Membuat Lembar Kerja Siswa (LKS) untuk kelompok. Pada setiap siklus siswa akan mengerjakan LKS kelompok 
sesuai materi yang di ajarkan siswa harus mampu bekerjasama untuk menyelesaikan tugas yang diberikan.

4) Menyusun instrument tes evaluasi untuk mengetahui peningkatan hasil belajar sisiwa, tes evaluasi untuk mengetahui yang dibuat adala sebanyak 5 butir soal esai.

5) Mengkonsultasikan instrument penelitian kepada dosen pembimbing. Siklus III terlaksana dalam satu kali pertemuan. Dalam pelaksanaan tindakan, dilakukan pengamatan berbagai komponen melalui lembar observasi aktifitas guru dan siswa. Penelitian membagi siswa menjadi enam kelompok

b. Tindakan Awal

Pelaksanaan siklus III dilakukan pada hari Juma't tanggal 8 September 2017, dimulai pukul 07:30 sampai 08:40 WIB dikelas IV SD Negeri Rahayu. Tahap kegiatan siklus I dimulai saat penelitian memasuki kelas pada pukul 07:30 WIB. Setelah siswa melakukan baris-berbaris didepan kelas, peneliti mengkondisikan siswa pada situasi pembelajaran yang kondusif dan menutun siswa untuk berdo'a bersama. Setelah berdo'a peneliti mengabsen siswa untuk mengetahui tingkat kehadiran siswa. Pada hari ini jumlah siswa yang hadir sebanyak 30 orang atau $100 \%$ siswa hadir.

Peneliti menyampaikan tujuan pembelajaran dan mempersiapkan siswa. Peneliti menjelaskan tentang operasi campuran, memberikan contoh tentang soal operasi campuran, dan mempersiapkan siswa untuk belajar dengan sedikit pemanasan (brain game). Siswa menyimak dan mencatat apa yang dijelaskan oleh guru. Peneliti mengadakan tanya jawab dari hasil penjelasan yang sudah diberikan. Peneliti membagi siswa menjadi 6 kelompok belajar dan setiap kelompoknya beranggota 5 orang.

c. Tindakan Inti

1) Tahap Presentasi Kelas

Pada tahap tindakan inti, peneliti memberikan soal pada setiap meja turnamen dengan jenis soal yang berbeda sesuai dengan kemampuan pada setiap kelompok. Pengundian ditentukan untuk menentukan kedudukan peserta 
turnamen dalam turnamen

pertama, apakah sebagai pembaca soal,penantang

pertama, penentang kedua yang disertai tugasnya masing-masing. Untuk putaran selanjutnya kedudukan peserta dilakukan secara bergantian, menurut arah jarum jam, sampai waktu turnamen selesai.

Siswa yang menjawab pertanyaanya benar, akan mendapatkan skor. Setiap perwakilan kembali pada anggota kelompoknya masing-masing dan memberitahukan kepada anggota kelompoknya tentang perolehan skor dan pertanyaan games. Siswa diberikan latihan soal mengenai opeasi hitung campuran Siswa membantu teman sekelompknya yang belum paham benar dalam mengerjakan soal. Peneliti bertanya tentang hal-hal yang belum dipahami siswa. Peneliti memberikan reward berupa pujian kepada kelompok turnamen yang mendapatkan nilai tertinggi dan memberikan penguatan kepada siswa.

2) Tahap Berlajar Kelompok
Agar siswa paham mengenai materi tersebut, peneliti membagikan Lembar Kerja Siswa (LKS). Masing-masing kelompok mendapatkan 1 LKS untuk dikerjakan secara berkelompok. Peneliti memberikan 15 menit kepada setiap kelompok untuk mengisi LKS tersebut. Pada saat pengerjaan LKS, peneliti bersama observer berkeliling untuk mengamati siswa. Setelah diamati, ada beberapa siswa yang tidak ikut serta dalam pengerjaan LKS bersama kelompoknya. Peneliti kemudian menghampiri siswa yang tidak ikut berpartisipasi dalam mengerjakan LKS tersebut dan menanyakan alasan mengapa mereka tidak ikut serta dalam pengerjaan LKS. Beberapa orang dari mereka beralasan bahwa sudah banyak yang mengerjakan sehingga mereka merasa tidak perlu ikut serta mengerjakan LKS.

Untuk mengatasi kekeliruan tersebut, peneliti mengulangi apa yang telah dijelaskan pada awal pembelajaran. Bahwa ini adalah pembeljaran kelompok, jadi segala sesuatu harus dilakukan dan dikerjakan bersama-sama, karena 
keberhasilan kelompok beukan karena beberapa anggota saja. Setelah peneliti menjelaskan hal tersebut, kemudian seluruh siswa mulai aktif bekerja sama dalam pengerjaan LKS. Setelah 15 menit, peneliti meminta sisw akelompok untuk mengumpulkan LKS yang telah dikerjakan dan bersiap-siap untuk kegiatan turnamaen.

3) Tahap Turnamen

Pada tahap turnamen ini, akan dilakukan game dimana setiap siklus siswa akan dibagi kedalam 6 meja turnamen, masingmasing meja berisi 4-5 orang dengan kemampuan yang sma (tinggi, diatas rata-rata, rata-rat, rendah) dan 5 kartu pertanyaan observasi memabantu penelitl untuk mengkondisikan siswa yang berebut tempat duduk agar tidak terjadi keributan. Setelah semua duduk di meja masing-masing turnamen, kemudian peneliti membagikan kartu soal dan kartu jawaban. Aturanya permainannya satu orang siswa mengambil kartu soal dan satu orang siswa mengambil kartu jawaban. Ketika siswa yang mengambil kartu soal menjawab benar, maka kartu soal dan kartu jawaban di simpan di dalam tempat pengumpulan kartu di setiap meja turnamen. Siswa yang menjawab soal pertanyaan benar mendapatkan skor 10 dan mencatatnya pada kartu perolehan skor. Ketika siswa yang mengambil kartu soal menjawab salah maka kartu soal dan jawaban di simpan kembali bagian bawah pada tumpukan soal pertanyaan dan jawaban.Pada sesi ketiga hampir $70 \%$ dari peserta dapat menjawab soal dengan baik yang ada dalam kartu soal.

4)Tahap Perhitungan Skor Dan Penghagaan

Pada tahap ini, peneliti meminta tiap kelompok mengumpulkan dan menghitung jumlah kartu soal yang telah berhasil dijawab untuk diubah menjadi poin. Kelompok yang masuk kategori Super Great yaitu Anggur skor 100, durian skor 100 , Leci skor 100, apel dengan skor 100 , strawberry dengan skor 80 , melon dengan skor 80 .

5) Observasi Siswa

Kegiatan observasi ini dilakukan oleh peneliti selama pembelajaran berlangsung. Hal ini 
yang diamati oleh observer adalah proses belajar atau aktivitas siswa dalam pembelajaran. Pengamatan yang dilakukan sesuai dengan pedoman observasi yang berisi aktivitas yang sesuai dengan Model Pembelajaran Teams Games Tounament (TGT). Sedangkan berdasarkan lembar observasi pada aktfitas belajar siswa dapat disimpulkan bahwa aktivitas belajar siswa yang mendominasi skala $\mathrm{A}$. Yang merupakan kategori Baik Sekali dengan skor 87,5 dalam lembar observasi.

\section{Kesimpulan}

Penelitian ini dapat di simpulkan bahwa pelaksanaan pembelajaran matematika dalam materi operasi hitung campuran pada siswa kelas $V$ SD Negeri Rahayu dengan menggunakan model pembelajaran Teams Games Tournament terbukti berhasil menyajikan pembelajaran yang menyenangkan. Sehingga keterampilan berpikir kritis siswadapat meningkat dengan menggunakan model pembelajaran Teams Games Tournament. Berdasarkan penelitian yang di lakukan, dari semua rangkaian kegiatan yang dimulai dari langkah persiapan, pelaksanaan, hingga analissi data maka, dapat di simpulkan sebagai berikut:

1. Hasil belajar siswa kelas IV SD Negeri Rahayu sebelum menggunakan model pembelajaran Teams Games Tournament masih rendah diukur dengan lembar tes awal siklus (Prasiklus). Hasil perolehan Prasiklus dengan menggunakan 30 butir pilihan ganda dengan populasi 30 siswa dan kriteria ketuntasan KKM sebesar 65 menunjukan bahwa sebanyak $76,7 \%$ atau 23 orang siswabelum berhasil mencapai KKM.

2. Pelaksanaan pembelajaran Teams Games Tournament dari mulai siklus I, II dan III mengalami peningkatan di mana siswa menjadi sangat aktif. Pada tahap menguji hipotesis dengan cara mempersentasikan hasil LKS secara begantian membuat mereka menanamkan rasa percaya diri dan diskusi secara aktif untuk mengembangkan proses berpikir secara maksimal. 
Didapat hasil dalam mengukur keterlaksanaan aktivitas guru dan siswa. Keterlaksanaan penampilan guru pada siklus I sebesar 3,1. Kemudian pada siklus II naik sebesar 3,3. Kemudian siklus III naik sebesar 3,7. Begitu pula dengan keterlaksanaan aktifitas siswa dalam siklus I sebesar 71,8. Siklus II naik sebesar 75,dan siklus III naik sebesar 87,5.

3. Hasil belajar siswa kelas IV SD Negeri Rahayu sesudah menggunakan model pebelajaran Teams Games Tournament mengalami peningkatan diukur dengan lembar tes siklus dan tes akhir siklus (Posttes). Hasil perolehan siklus I dengan menggunakan sepuluh butir pilihan ganda dengan materi operasi hitung campuran 15 orang siswa $50 \%$ atau 15 siswa telah mencapai KKM sedangkan $50 \%$ atau 15 lainya belum mencapai KKM dengan presentasi rata-rata kelas sebesar 65,1. Pada saat siklus II yang mencapai KKM meningkat menjadi $86,7 \%$. Pada siklus III menjadi 100\%.

\section{DAFTAR PUSTAKA}

Anita Lie, (2005) Cooperative Learning. Jakarta: Grasindo

Arikunto, Suharsimi. (2006) Prosedur Penelitian Suatu Pendekatan Praktek. Jakarta: PT. Rineka Cipta

Depdiknas, (2003:5) Undang-

Undang Republik Indonesia No 20 Tahun 2003 tentang Sistem Pendidikan Nasional

Hasratuddin, (2013). Membangun Karakter Melalui Pembelajaran Matematika [online], Jurnal Pendidikan Matematika PARADIKMA, Vol 6 Nomor 2, hal $\quad 130$. Tersedia :http://digilib.unimed.ac.id/960/ 2/FullText.pdf. [27 Mei 2017] Hermawan Ruswardi dkk, 2007. Metode penelitian sekolah dasar hernowo, quantum writing. Bandung: Mizan learning Center

Kenneth D. Moore, (2005) Effective instructional Strategis From Theory to Practice. London:Publication

Kurikulum Tingkat Satuan

Pendidikan (2006). Jakarta Lestari, K.E dan Yudhanegara, M.R (2015). Penelitian Pendidikan 
Matematika. Bandung: PT

Refika Aditama.

Manrihu (Hadis.A 2006:23)

Pisikologi dalam

Pendidikan.Bandung: Alfabeta.

Moh. Uzer Usman, (2000:5).

Menjadi GuruProfesional

Bandung: Remaja Rosdakarya Muhsetyo, dkk

(2008:2)

Pembelajaran matematika $S D$.

Jakarta: Universitas Terbuka.

Muslich, M. (2009) Melaksanakan

Penelitian Tindakan Kelas itu

Mudah (Classroom Action

Research). Jakarta: Bumi

Aksara.

Nana Sudjana, (2008) Penilaian

Hasil Proses Belajar Mengajar.

Bandung: PT Remaja

Rosdakarya.

Nandang, (2015). Penerapan

Model Pembelajaran

Kooperatif Tipe Teams Games

Tournament

Untuk

Meningkatkan Pemahaman

Matematika Siswa Sekolah

Dasar Pada Materi Oprasi

Hitung Penjumlahan Dan

Pengurangan Tiga Angka.

STKIP Subang :Skripsi
Nasution, A. H (Karso,dkk 2008: 1.39) Landasan Matematika. Jakarta: Bhatara Aksara.

Niaga, A, (2013). Model Pembelajaran Team Games Tournament (TGT). [Online]. Tersedia:http://www.academia. edu/4575759/artikel_MODEL_ PEMBELAJARAN_TEAMS_G AMES_TOURNAMENTS [9 Juni 2017]

Nuraini, S, (2014). Pengertian Matematika. [online]. Tersedia: http://digilib.uinsby.ac.id/849/5/ Bab\%202.pdf [26 Mei 2017] Retno, A (2015). "Penggunaan Alat Peraga Tiga Dimensi Untuk Meningkatkan Pemehaman Konsep Matematika Siswa Pada Pembelajaran Bangun Ruang”. Skripsi Sarjana, STKIP Subang: tidak diterbitkan.

Rusman. (2013) Model-Model

Pembelajaran. Jakarta: PT Rajagrafindo Persada

Russeffendi, E. T (1988:2) Pengajaran Matematika Modern dan Masa Kini Untuk Guru SD dan SPG. Bandung: Tarsito. 
Salvin, R. E (2010). Cooperative Learning, Teori, Riset and Practik. Bandung: Nursamedia. Sanjaya (Rusman :2013:203) Coopeative learning merupakan kegiatan belajar siswa yang dilakukan dengan cara berkelompok.. Jakarta

Sugiyono, (2009). Metode

Penelitian Kuantitatif, Kualitatif dan R \& D. Bandung: Alfabeta. Sujarwo, (2008 ). Metode Pembelajaran Pendidikan Keaksaraan. hl 1.Yogyakarta: Universitas Negeri Yogyakarta. Susanto, A. D (2015). Upaya Meningkatkan Hasil Belajar Matematika Melalui Pembelajaran Kooperatif Tipe Team Games Tournamen Pada Siswa Kelas V Sd N 1 Jembangan Poncowarno Kebumen. Universitas PGRI Yogyakarta: Skripsi

Syarifuddin, A. (2011). Belajar Dan Faktor-Faktor Yang Mempengaruhinya [online], TA'DIB, Vol. XVI, No. 01, Edisi Juni 2011, 125. Tersedia: http://jurnal.radenfatah.ac.id/in dex.php/tadib/article/download/ 57/52 [27 Mei 2017]
Trianto. (2010: 241). Mendesain Model Pembelajaran InovatifProgresif: Konsep, Landasan, dan Implementasinya pada Kurikulum Tingkat Satuan Pendidikan (KTSP). Jakarta: Kencana Prenada Media Group.

Wasita, R. (2013). "Penerapan Pendekatan Pembelajaran Kontruktivisme Sebagai Upaya Meningkatkan Pemahaman Konsep Matematis Siswa Kelas V Sekolah Dasar". Skripsi Sarjana, UPI Purwakarta: tidak diterbitkan.

Yulianto,W.D, dkk (2016:324). Model Pembelajaran Teams Games Tournament Untuk Meningkatkan Hasil Belajar Siswa Smk , Journal of Mechanical Engineering Education, Vol.1, No.2, Desember 2014 [Online]. Tersedia:http://ejournal.upi.edu /index.php/jmee/article/downlo ad/3820/2723 [30 Mei 2017] 